\title{
Effects of cold storage temperature treatments on fruit quality attributes in 'Hongro' apples
}

\author{
Jingi Yoo ${ }^{1}$, Seung-Yeol Lee ${ }^{2}$, Nay Myo Win ${ }^{1}$, Soon-Il Kwon ${ }^{3}$, Hee-Young Jung ${ }^{2}$, \\ Young-Je Cho ${ }^{4}$, In-Kyu Kang ${ }^{1 *}$ \\ ${ }^{1}$ Department of Horticultural Science, Kyungpook National University, Daegu 41566, Korea \\ ${ }^{2}$ School of Applied Biosciences, Kyungpook National University, Daegu 41566, Korea \\ ${ }^{3}$ Apple Research Institute, National Institute of Horticultural and Herbal Science, RDA, Gunwi 39000, Korea \\ ${ }^{4}$ School of Food Science and Biotechnology, Kyungpook National University, Daegu 41566, Korea
}

\section{저온저장 온도처리가 ‘홍로’ 사과의 저장중 과실품질에 미치는 영향}

\author{
유진기 ${ }^{1} \cdot$ 이승열 ${ }^{2} \cdot \mathrm{Nay} \mathrm{Myo}_{\mathrm{Win}^{1}} \cdot$ 권순일 $^{3} \cdot$ 정희영 ${ }^{2} \cdot$ 조영제 ${ }^{4} \cdot$ 강인규 $^{1 *}$ \\ ${ }^{1}$ 경북대학교 원예과학과, ${ }^{2}$ 경북대학교 응용생명과학부, ${ }^{3}$ 국립원예특작과학원 사과연구소, \\ 4경북대학교 식품공학부
}

\begin{abstract}
This study was conducted to elucidate the effects of different storage temperatures on fruit quality attributes and storage disorders in cold-stored 'Hongro' apples. 'Hongro' apples were harvested from two different regions-Mungyeong, Gyeongsangbukdo, and Geochang, Gyeongsangnamdo, -and then stored for 4 months at $0^{\circ} \mathrm{C}$ and/or $4^{\circ} \mathrm{C}$, respectively. Fruit firmness and titratable acidity of 'Hongro' apples were decreased during cold storage but there were no significant differences between storage temperatures. Moreover, storage at different temperatures did not influence the soluble solids content of 'Hongro' apples from the two regions during cold storage. However, the intemal ethylene concentration of 'Hongro' apple was increased at $4^{\circ} \mathrm{C}$ relative to that at $0^{\circ} \mathrm{C}$, regardless of the harvested regions. In addition, the greasiness (wax) index of fruit in both regions increased at $4^{\circ} \mathrm{C}$, compared with at $0^{\circ} \mathrm{C}$. The incidence of fruit peel disorder was higher at $0^{\circ} \mathrm{C}(8.1-9.4 \%)$, than at $4{ }^{\circ} \mathrm{C}(1.3-4.7 \%)$ after 4 months of storage. Moreover, the four pathogens isolated from the symptomatic fruit peel were identified as Penicillium sp., Alternaria sp., Phoma sp., and Botryosphaeria dothidea. Therefore, to more effectively suppress fruit peel disorder, it is more effective to store 'Hongro' apple at $4^{\circ} \mathrm{C}$ rather than at $0^{\circ} \mathrm{C}$.
\end{abstract}

Key words : apple, storage temperature, fruit peel disorder, storability

\section{서 론}

‘홍로' 사과는 국내에서 육성된 중생종 품종으로 추석 출하를 통해 농가 소득에 크게 이바지함으로서 그동안 재배 면적이 급속히 증가하여 국내 제 2 의 품종으로 자리잡고 있지만(1) 저온저장 중 과피반점 형태의 저장장해가 발생하

*Corresponding author. E-mail : kangik@knu.ac.kr Phone : 82-53-950-5727, Fax : 82-53-950-5722

Received 6 September 2018; Revised 5 October 2018; Accepted 8 October 2018.

Copyright (c) The Korean Society of Food Preservation. All rights reserved.
는 문제점이 제기되고 있다. 과실의 저장성은 저장 온도가 상승함에 따라 과실의 경도 및 산 함량 감소, 조직의 연화, 부패 등 품질저하가 발생하게 되므로 최적의 저온조건을 설정하게 된다(2). 이러한 과실의 저장시 저온조건은 부패 균의 증식과 함께 생물의 대사작용을 억제함으로서 과실의 저장기간을 연장시키지만, 과실의 품종에 따라 저장시 저 온이 다양한 저온장해를 유발할 수 있어 과실품질을 유지하 는데 적합한 온도를 설정하는 것이 중요하다(3). 현재 우리 나라에서 사용되고 있는 사과의 저온저장 온도는 $0 \pm 1{ }^{\circ} \mathrm{C}$, 습도는 $85-90 \%$ 로서 $(2,4)$ 이는 만생종 '후지' 사과의 저장 조건으로 조생종과 중생종 사과의 적정 저장온도에 대한 연구는 없는 실정이다. 
그 동안의 연구 결과들에서 사과 저온저장 시 과실 내·외 부에 발생하는 장해를 보면 내부갈변, 저온내부장해, 과심 부 갈변장해 등이 다양하게 발생하고 있고, 이는 저온에 의해 발생하는 경우가 많은 것으로 보고되고 있다(5-9). 사 과의 경우 일반적으로 $0-0.5^{\circ} \mathrm{C}$ 에 저장을 하지만 온도에 민 감한 품종의 경우 저온장해를 유발하게 되고, 이때 저장온 도를 높여주면 ‘콕스오렌지피핀'(10), ‘크립스핑크'(11), '엠파이어'(9,12,13), ‘후지'(14), 그리고 '허니크리스프' (15-17) 등의 사과에서 저장장해를 감소시켜 과실품질을 유지하는데 효과가 있다고 하였다 $(18,19)$. 최근 본 연구자 들이 조사한 결과 '홍로' 사과의 경우 $0^{\circ} \mathrm{C}$ 에 저장할 경우 과피에 음각형태로 조직이 괴사하는 새로운 형태의 저장장 해(Fig. 1)가 적게는 $10 \%$ 정도, 심한 곳은 $30 \%$ 이상 발생하 여 농가에 경제적인 손실이 발생하고 있다.

따라서 본 연구는 '홍로' 사과를 저장온도 처리에 따라 과피 저장장해 발생 정도와 과실품질에 미치는 영향을 구명 하고자 실시하였다.

\section{재료 및 방법}

\section{실험재료}

본 실험은 경상남도 거창군 고제면과 경상북도 문경시 마성면 소재에 위치한 2개 지역 과수원에 재식되어 있는 ‘홍로/M.9'(9년생) 나무를 대상으로 수세가 안정된 나무에 서 과실을 수확하였다. 과실의 수확일은 2017년 9월 10일이 었고, 과실을 수확후 외형적인 상처나 병반이 없는 과실만 을 분류하여 실험재료로 사용하였다.

\section{저장 조건 및 과실 특성 조사}

과실의 저장조건은 관행 저장온도인 $0^{\circ} \mathrm{C}$ 와 $4{ }^{\circ} \mathrm{C}$ 로 설정한 2 처리구를 두어 과실을 저장하였고, 상대습도는 $90 \%$ 로 설 정하였다. 이때 저온저장고의 온도편차는 $\pm 1{ }^{\circ} \mathrm{C}$ 정도였다. 과실의 저장기간은 총 4 개월간 실시하였으며, 과실의 품질 조사는 수확시(9월 10일), 과피에 음각형태의 저장장해가
발생하는 시점인 저장 2 개월 후(11월 10 일), 3 개월 후(12월 10 일), 4개월 후(1월 10 일)에 실시하였다.

과실의 경도는 직경 $11 \mathrm{~mm}$ plunger를 장착한 rheometer (Compac-100П, Sun Scientific Co., Tokyo, Japan)를 사용하 여 과실 적도부의 과피를 제거한 다음 과실 당 3회 측정한 값을 평균하여 Newton(N)으로 나타내었다. 산 함량은 전위 차 적정기(DL-15, Mettler Toledo Co., Greifensee, Switzerland) 를 사용하여 과즙 $5 \mathrm{~mL}$ 에 증류수 $45 \mathrm{~mL}$ 을 추가한 뒤 0.1 $\mathrm{N} \mathrm{NaOH}$ 로 $\mathrm{pH}$ 8.1까지 적정한 후 사과산으로 환산하였고, 가용성 고형물 함량은 디지털당도계(PR-201a, Atago Co., Ltd., Tokyo, Japan)를 이용하여 측정하였다. 왁스발생정도 는 건전과는 0 , 매우 약한 미끌거림 1 , 약간 미끌거림 2 , 미끌거림 3 , 많이 미끌거림 4 , 매우 많이 미끌거림 5 로 구분 하여 관능적으로 평가하였다(20). 과실특성조사는 5 개를 1 반복으로 하여 3 반복 15 개의 과실을 대상으로 조사하였 고, 과피장해 발생률은 40 개 과실을 1 반복으로 하여 3 반복 120 개의 과실을 대상으로 총 과실에서 장해가 발생하는 과실의 비율을 백분율로 나타내었다.

\section{내생 에틸렌 발생량}

내생 에틸렌 발생량은 조사 1 일전에 과실을 저장고에서 꺼내어 실온 $\left(25^{\circ} \mathrm{C}\right)$ 에서 품온을 평형시킨 후 측정하였다. $1 \mathrm{~mL}$ 주사기를 꽃받침 부위에 삽입하여 과심 내 gas $1 \mathrm{~mL}$ 를 채취한 뒤 $\mathrm{FID}$ (flame ionization detector)를 장착한 gas chromatography(GC2010, Shimadzu, Kyoto, Japan)를 이용 하여 측정하였다. Gas chromatography의 분석 조건은 Porapak Q(80/100, Youngin Frontier, Seoul, Korea) column 을 이용하였으며, injector temperature $200^{\circ} \mathrm{C}$, oven temperature $90^{\circ} \mathrm{C}$, detector temperature $200^{\circ} \mathrm{C}$ 로 설정하였고, carrier gas는 $\mathrm{He}$, flow rate는 분당 $25 \mathrm{~mL}$ 로 하였다.

\section{병원균 분리 및 동정}

병원균을 동정하기 위해 과피 장해증상이 나타난 부위의 조직을 분리하여 병원균을 배양하였다. 이를 위하여 채집 된 과실을 $70 \%$ ethanol을 이용하여 가볍게 닦아내고, 화염
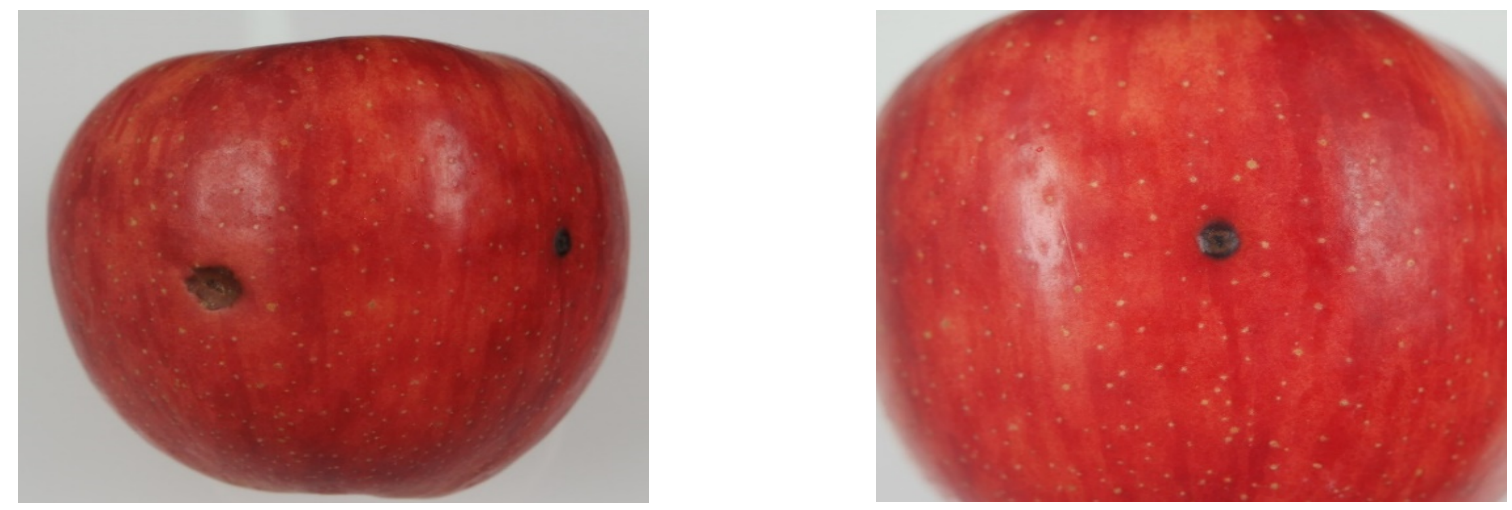

Fig. 1. Fruit peel disorder showing hollow-relief shape newly observed in 'Hongro' apple. 
소독한 메스를 이용하여 장해증상 부분을 절개 후 관찰되는 내부 조직을 감자한천배지(potato dextrose agar, PDA; Difco, Sparks, MD, USA)에 치상하여 $25^{\circ} \mathrm{C}$ 암조건에서 배양 하였다. 배양 2-3일 후 형성된 흰색 균사를 새로운 PDA 배지에 옮겨 계대 배양하였다. 분리 균주의 동정을 위해,

Higene Genomic DNA Prep Kit(BIOFACT, Daejeon, Korea) 를 이용하여 제조사의 방법대로 total genomic DNA를 추출 한 뒤, ITS1F/ITS4 프라이머를 이용하여 internal transcribed spacer(ITS) 영역을 증폭하여 염기서열을 의뢰한 후(Solgent, Daejeon, Korea) 병원균을 분석 및 동정하였다. 염기서열은 미국 국립생물공학정보센터(National Center for Biotechnology Information, NCBI)에서 Basic Local Alignment Search Tool(BLAST) 방법을 통해 상동성 분석을 수행하였다,

\section{통계분석}

통계분석은 SPSS 프로그램(IBM SPSS Statistics 20, SPSS Inc., Armonk, NY, USA)을 이용하여 ANOVA 결과 분석 후 과실 품질 항목별로 Duncan 다중검정으로 분석하였다.

\section{결과 및 고찰}

\section{과실품질 특성}

문경과 거창지역 ‘홍로' 사과의 수확 시 과실품질 특성을 보면(Table 1), 과중, 산 함량, 왁스 발생 정도, 과피 장해 발생, 적색도는 두 지역간 차이를 보이지 않았다. 그러나 경도와 가용성 고형물 함량의 경우 문경지역의 과실이 다소 높았고, 내생에틸렌 발생량은 거창지역의 과실이 다소 높 은 경향을 보여 거창지역의 과실 성숙이 다소 더 진행된 것을 확인하였다.

문경과 거창지역의 ‘홍로' 사과를 저장온도별 저장기간 에 따른 과실의 경도변화를 보면(Fig. 2), 문경지역 과실의 경우 저장 2 개월 후 $0^{\circ} \mathrm{C}$ 저장처리구는 $68.2 \mathrm{~N}$ 과 $4^{\circ} \mathrm{C}$ 저장처 리구는 $66.2 \mathrm{~N}$ 이었고, 저장 4 개월 후에는 $0^{\circ} \mathrm{C}$ 와 $4^{\circ} \mathrm{C}$ 저장처 리구는 각각 $61.6 \mathrm{~N}$ 과 $62.3 \mathrm{~N}$ 으로 다소 감소하는 경향을 보였으나 저장온도에 따른 차이는 없었다. 거창지역의 과 실 역시 문경지역 과실과 같은 경향으로 저장온도에 따른
차이는 보이지 않았고 경도가 저장 4 개월 후 $0^{\circ} \mathrm{C}$ 와 $4^{\circ} \mathrm{C}$ 저장처리구는 각각 $53.6 \mathrm{~N}$ 과 $52.4 \mathrm{~N}$ 으로 다소 감소하였다. 산 함량의 변화를 보면(Fig. 2), 문경지역 과실의 경우 저장 2 개월 후 $0{ }^{\circ} \mathrm{C}$ 와 $4^{\circ} \mathrm{C}$ 저장 처리구 모두 $0.17 \%$ 이던 산 함량이 저장 4 개월 후 두 처리에서 $0.13 \%$ 수준으로 감소하였다. 그리고 거창지역 역시 저장 2 개월 후 $0^{\circ} \mathrm{C}$ 와 $4^{\circ} \mathrm{C}$ 저장처리구 모두 $0.18 \%$ 이던 산 함량이 저장 4 개월 후 $0{ }^{\circ} \mathrm{C}$ 저장처리구 $0.13 \%$ 와 $4{ }^{\circ} \mathrm{C}$ 저장처리구 $0.15 \%$ 로 다소 감소하였으나 저장 온도 처리에 따른 차이가 없었다. 이러한 결과를 보면 저장 온도에 따른 과실의 품질은 차이를 보이지 않았으나 재배지 에 따른 과실의 경도 차이가 있는 것은 과수원의 위치, 토양 조건, 시비조건, 동일한 시기의 수확으로 인한 과실의 성숙 정도 등에 따른 차이에서 발생한 결과라고 판단되었다. 저 장기간동안 두 지역 모두 저장온도 처리별 과실의 가용성 고형물 함량의 변화는 뚜렷한 차이를 보이지 않았다(Fig. 2). 일반적으로 사과 과실에 있어 경도와 산 함량은 저장기 간동안 과실의 품질을 평가하는데 있어 중요한 요소로 평가 되고 있다. 과실의 경도와 산 함량은 호흡량에 영향을 받기 때문에 저장온도가 낮을수록 호흡량을 감소시켜 장기간 과실품질을 유지할 수 있다(21). 그러나 품종에 따라 적정한 저장온도는 다르며 미국 뉴욕지역에서 생산된 '허니크리스 프, 사과품종의 경우 $0.5^{\circ} \mathrm{C}$ 와 $2.8^{\circ} \mathrm{C}$ 로 각각 저장하였을 때 12 주간 저장후 경도와 산 함량은 차이가 없었고, 미시건지 역에서 생산한 사과의 경우도 $0^{\circ} \mathrm{C}$ 와 $3^{\circ} \mathrm{C}$ 에 각각 저장하였을 때 12 주 후 과실의 경도와 산 함량, 그리고 가용성 고형물 함량의 차이가 없다고 하여 $(17,22)$ 본 연구결과와 동일한 경향을 보였다.

\section{내생에틸렌 발생량과 왁스 발생 정도}

저장온도 처리에 따른 과실의 내생에틸렌 발생량을 보면 (Fig. 3 ), $4^{\circ} \mathrm{C}$ 저장처리구는 저장 2 개월 후 문경지역의 과실 은 $31.8 \mu \mathrm{L} / \mathrm{L}$, 거창지역의 과실은 $121.8 \mu \mathrm{L} / \mathrm{L}$ 였고, $0^{\circ} \mathrm{C}$ 저장 처리구는 문경지역은 $11.3 \mu \mathrm{L} / \mathrm{L}$, 거창지역은 $35.9 \mu \mathrm{L} / \mathrm{L}$ 의 발생량을 보였다. 저장 4 개월 후 역시 $4{ }^{\circ} \mathrm{C}$ 저장처리구는 문경지역은 $39.2 \mu \mathrm{L} / \mathrm{L}$, 거창지역은 $202.0 \mu \mathrm{L} / \mathrm{L}$ 으로 발생량 이 크게 증가하였나, $0^{\circ} \mathrm{C}$ 저장처리구는 문경지역은 29.8 $\mu \mathrm{L} / \mathrm{L}$, 거창지역은 $47.9 \mu \mathrm{L} / \mathrm{L}$ 로 $4^{\circ} \mathrm{C}$ 저장처리구와 비교하여

Table 1 . Fruit quality attributes in two regions 'Hongro' apples at harvest

\begin{tabular}{ccccccccc}
\hline Regions & $\begin{array}{c}\text { Fruit weight } \\
(\mathrm{g})\end{array}$ & $\begin{array}{c}\text { Flesh firmness } \\
(\mathrm{N} / \Phi 11 \mathrm{~mm})\end{array}$ & $\begin{array}{c}\text { Titratable acidity } \\
(\%)\end{array}$ & $\begin{array}{c}\text { Soluble solids } \\
\text { content } \\
\left({ }^{\circ} \mathrm{Brix}\right)\end{array}$ & $\begin{array}{c}\text { Internal ethylene } \\
\text { concentration } \\
(\mu \mathrm{L} / \mathrm{L})\end{array}$ & $\begin{array}{c}\text { Greasiness } \\
(0-5)\end{array}$ & $\begin{array}{c}\text { Fruit peel } \\
\text { disorder } \\
(\%)\end{array}$ & $\begin{array}{c}\text { Hunter's } \\
\text { Value } \\
\mathrm{a}\end{array}$ \\
\hline Mungyeong & $291.0 \pm 20.3$ & $71.5 \pm 1.1$ & $0.19 \pm 0.01$ & $13.9 \pm 0.28$ & $1.3 \pm 0.32$ & $0.20 \pm 0.12$ & $0.0 \pm 0.0$ & $24.5 \pm 0.91$ \\
Geochang & $334.7 \pm 22.0$ & $68.0 \pm 0.5$ & $0.18 \pm 0.00$ & $12.6 \pm 0.07$ & $14.8 \pm 2.23$ & $0.00 \pm 0.00$ & $0.0 \pm 0.0$ & $24.2 \pm 0.37$ \\
\hline Significance & $\mathrm{NS}^{1)}$ & $*$ & $\mathrm{NS}$ & $* *$ & $*$ & $\mathrm{NS}$ & $\mathrm{NS}$ & NS \\
\hline
\end{tabular}

${ }^{1)} \mathrm{NS},{ }^{*}, *$ non-significant or significant at $\mathrm{p}<0.05$ or $\mathrm{p}<0.01$, respectively. 

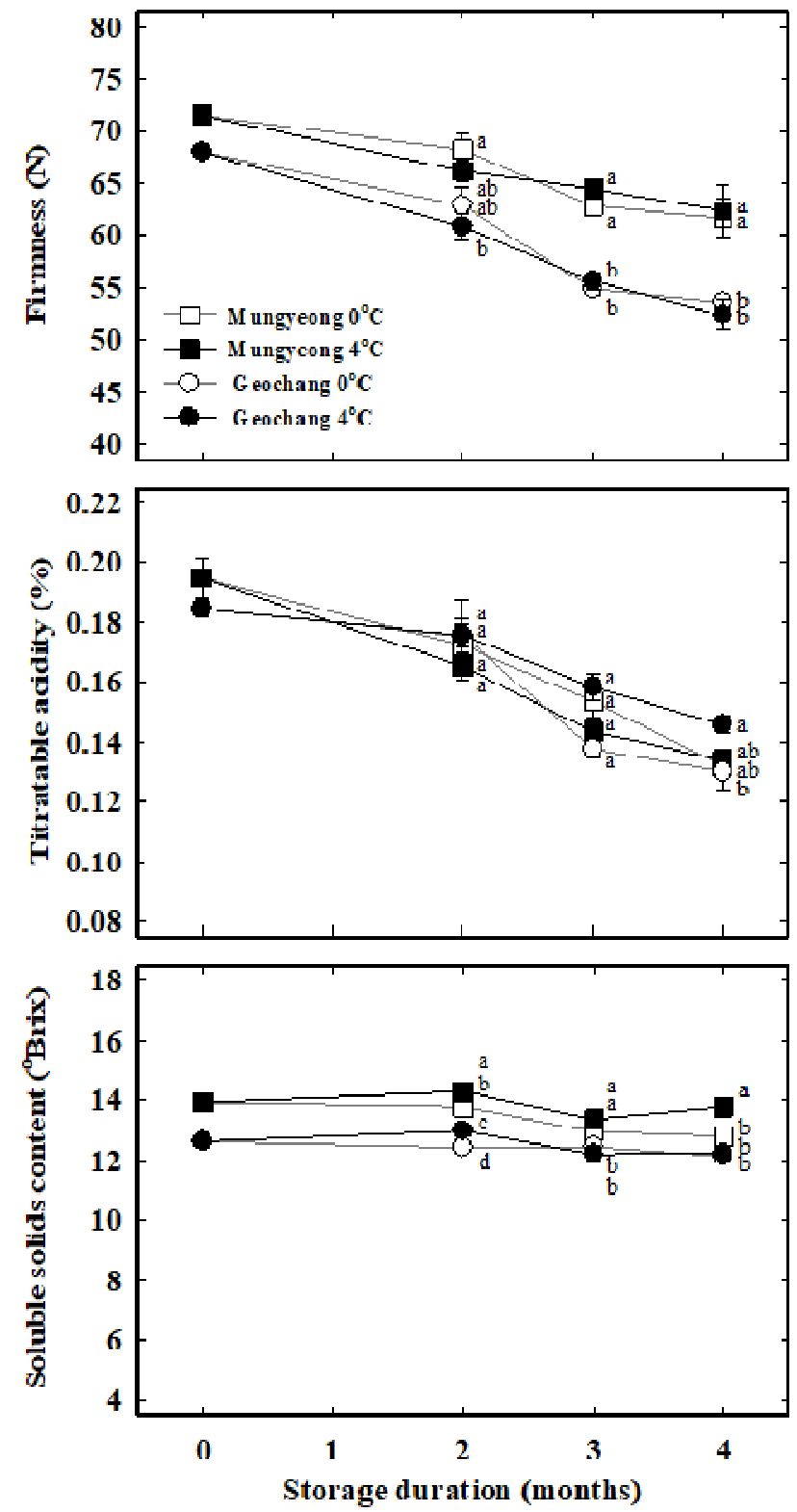

Fig. 2. Effects of different storage temperature on firmness, titratable acidity, and soluble solids content in cold-stored 'Hongro' apples at Mungyeong and Geochang regions.

Mean separation within columns by Duncan's multiple range test at $\mathrm{p}=0.05$. All values are expressed as mean \pm SE $(n=15)$.

낮은 에틸렌 발생량을 보였다. 결과를 보면 과실의 재배지 환경에 따른 에틸렌 발생량에 차이가 있었고, 저장온도가 낮을수록 에틸렌 발생량이 감소하였지만 과실의 품질에는 차이를 보이지 않았다. 특히, 거창지역의 과실이 문경지역 의 과실보다 에틸렌 발생량이 높고, 과실의 경도가 감소한 것은 거창지역의 과실 성숙이 더 빨리 진행되었음을 확인할 수 있었다.

과실의 왁스 발생정도를 보면(Fig. 3), $4^{\circ} \mathrm{C}$ 저장처리구의 경우 저장 2 개월 후 문경지역의 과실은 1.4 , 거창지역은 0.7 정도였고, $0{ }^{\circ} \mathrm{C}$ 저장처리구는 문경지역은 1.0 , 거창지역
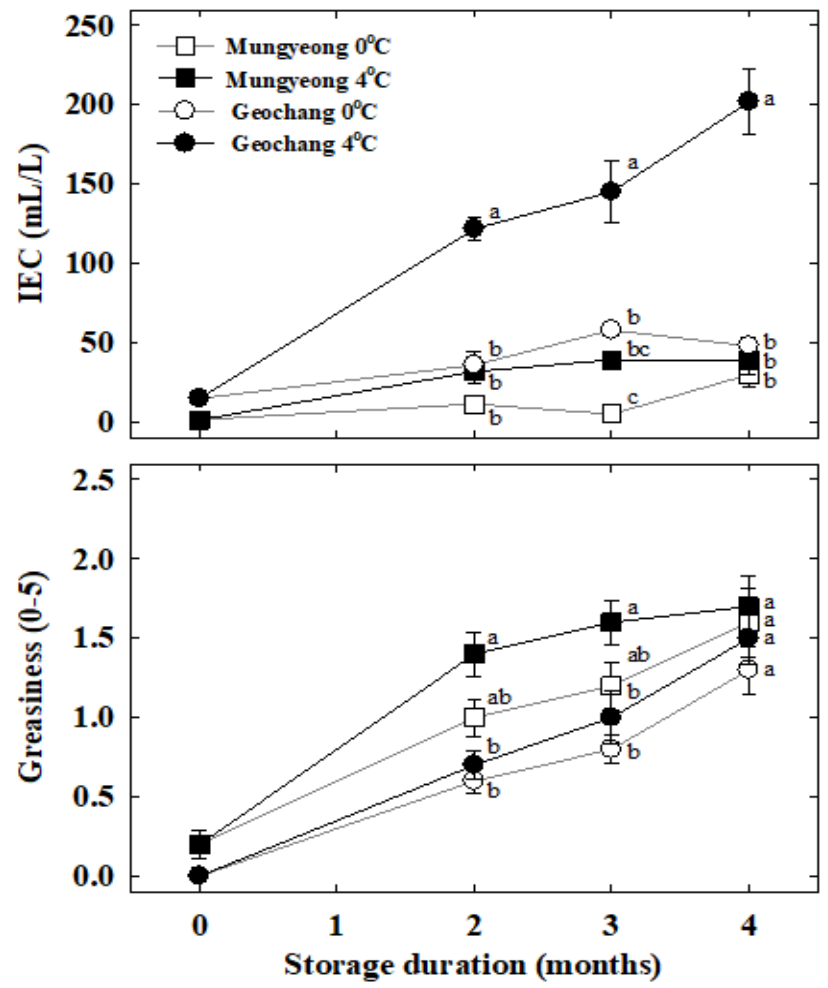

Fig. 3. Effects of different storage temperature on internal ethylene concentration (IEC) and fruit peel greasiness in cold-stored 'Hongro' apples at Mungyeong and Geochang regions.

Greasiness index: 0 , no slippery; 1 , very low slippery; 2 , low slippery; 3 , middle slippery; 4 , high slippery; 5 , very high slippery.

Mean separation within columns by Duncan's multiple range test at $\mathrm{p}=0.05$. All values are expressed as mean \pm SE $(n=15)$.

은 0.6 정도의 발생을 보였다. 그리고 저장 4 개월 후에는 $4{ }^{\circ} \mathrm{C}$ 저장처리구는 문경지역은 1.7 , 거창지역은 1.5 로 왁스 발생정도가 증가하였으나, $0^{\circ} \mathrm{C}$ 저장처리구는 문경지역과

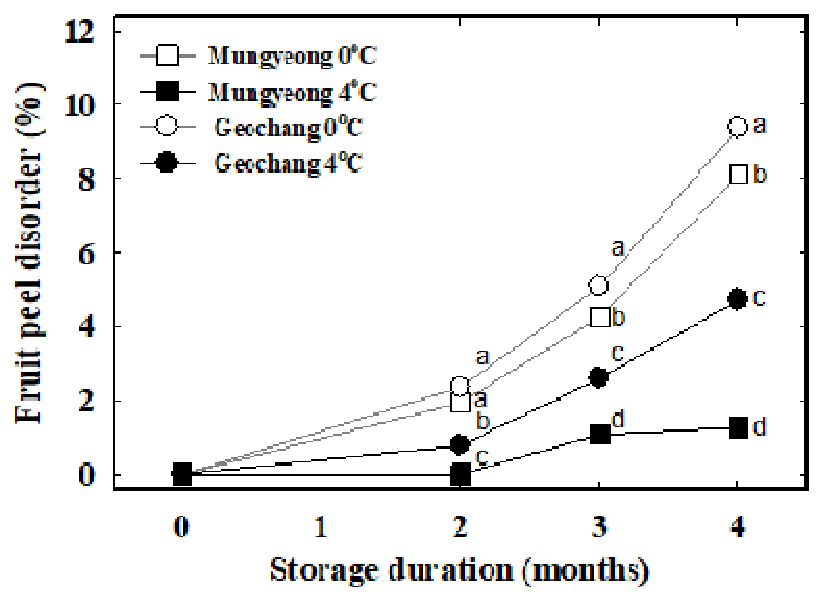

Fig. 4. Effects of different storage temperature treatments on fruit peel disorder rate in cold-stored 'Hongro' apples at Mungyeong and Geochang regions.

Mean separation within columns by Duncan's multiple range test at $\mathrm{p}=0.05$. All values are expressed as mean $\pm \mathrm{SE}(\mathrm{n}=120)$. 


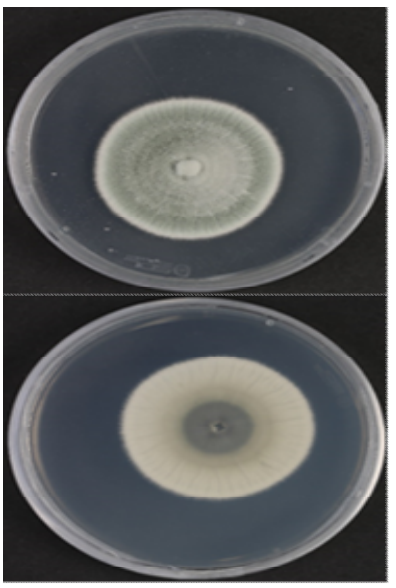

Penicillium sp.

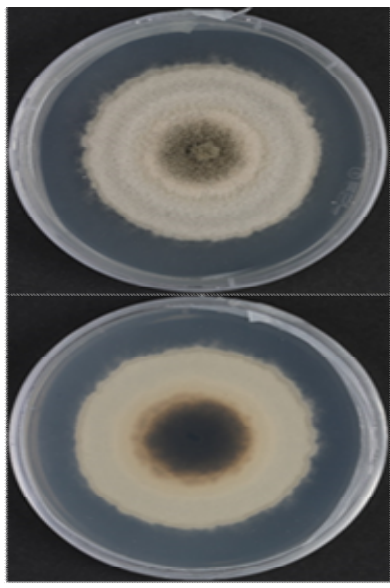

Alternaria sp.

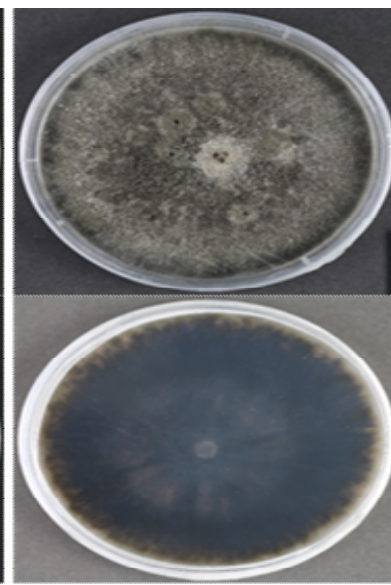

Phoma sp.

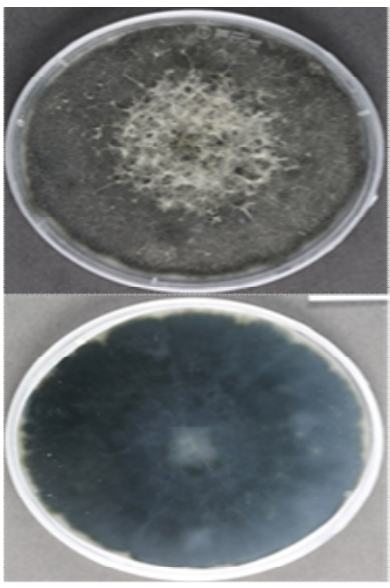

Botryosphaeria dothidea

Fig. 5. Morphological characteristics of several pathogens from fruit peel disorder in cold-stored 'Hongro' apples. Gene number in NCBI. Penicillium sp. (MH865544), Alternaria sp. (MG827168), Phoma sp. (KR708991), Botryosphaeria dothidea (MG595271).

$0^{\circ} \mathrm{C}$

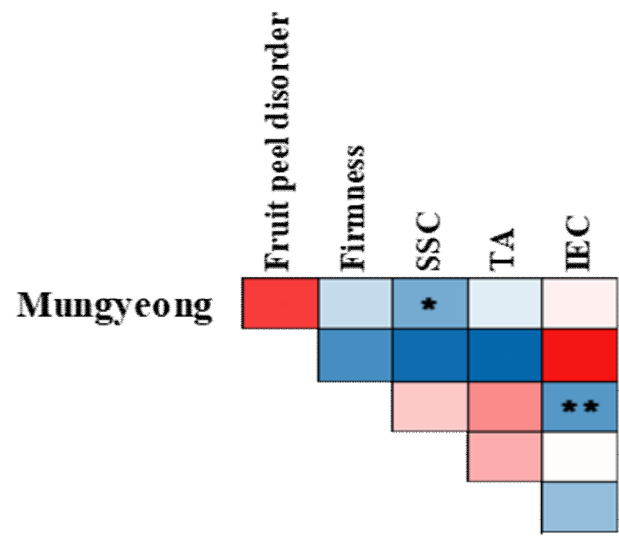

$4^{\circ} \mathrm{C}$

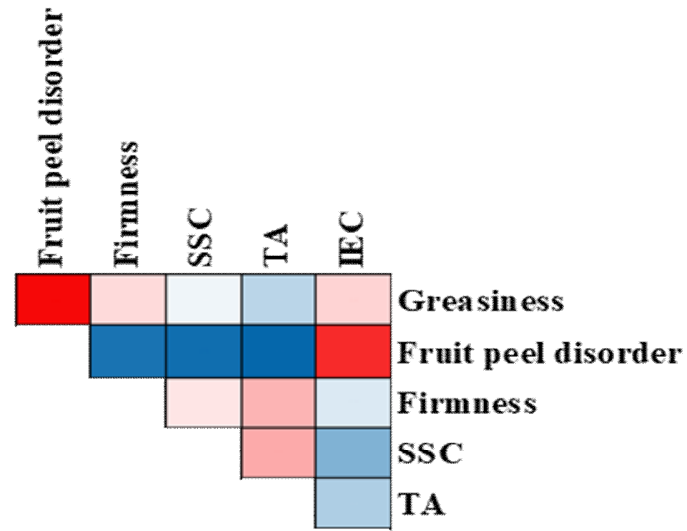

\section{Geochang}

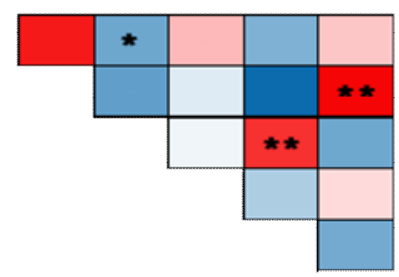

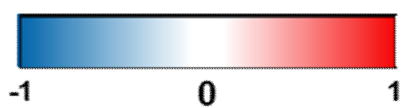

Fig. 6. Pearson correlation coefficient (r) for fruit quality attributes in different storage temperature in cold-stored 'Hongro' apples at Mungyeong and Geochang regions.

Red and blue indicate positive and negative correlation between the fruit quality attributes, respectively. Asterisks ${ }^{*}{ }^{*}$ or $\left.{ }^{*}\right)$ indicate statistically significant correlation at $p<0.05$, or $\mathrm{p}<0.01$, respectively.

거창지역의 과실에서 각각 1.6 과 1.3 으로 $4{ }^{\circ} \mathrm{C}$ 저장 처리구 와 비교하여 과피 왁스의 발생이 다소 낮은 결과를 보이기 는 했으나 그 차이는 크지는 않은 것으로 나타났다. Watkins 등(17)은 사과의 저장온도를 $0.5^{\circ} \mathrm{C}$ 와 $2.8^{\circ} \mathrm{C}$ 또는 $0^{\circ} \mathrm{C}$ 와 $3^{\circ} \mathrm{C}$
로 하여 저장하였을 때 과실의 경도와 산 함량에는 영향을 미치지 않지만 내생에틸렌의 발생량은 상대적으로 높은 저장온도에서 발생량이 많았다고 하였다. $\operatorname{Lim}$ 등(4)도 역시 호흡과 에틸렌 발생량은 저장온도의 영향을 크게 받으며, 
특히 에틸렌의 경우 한번 생성된 에틸렌은 자가촉매적인 역할을 통하여 에틸렌의 생성을 촉진시킨다고 하였다. 그 리고 과피의 왁스발생 정도 역시 상대적으로 높은 저장온도 로 인한 에틸렌의 증가가 가역적으로 영향을 미쳐 왁스발생 도 동일한 경향으로 증가한다고 하여(22) 본 연구결과와 일치하는 경향을 보였다.

\section{과피장해 발생률과 병원균 분석}

저장온도에 따른 과실의 과피장해 발생률을 보면(Fig. 4), 문경지역 '홍로' 과실의 경우 $0^{\circ} \mathrm{C}$ 저장처리구는 저장 2 개월 후 $1.9 \%$ 였고, 거창지역의 과실은 $2.4 \%$ 의 발생률을 보였다. 그러나 $4^{\circ} \mathrm{C}$ 저장처리구의 과실은 문경지역은 $0 \%$ 였 고, 거창지역은 $0.8 \%$ 로 그 발생율이 낮았다. 이후 저장기간 동안 장해 발생률은 점차 증가하여 저장 4 개월 후 $0^{\circ} \mathrm{C}$ 저장 처리구의 경우 문경과 거창지역은 각각 $8.1 \%$ 와 $9.4 \%$ 로 장 해발생률이 급격히 증가하였다. 그러나 $4{ }^{\circ} \mathrm{C}$ 저장처리구의 경우에는 저장 4 개월 후 문경지역은 $1.3 \%$, 거창지역은 $4.7 \%$ 로 과피 장해발생 정도가 $0^{\circ} \mathrm{C}$ 저장 처리구와 비교하여 문경지역의 과실은 $15.6 \%$, 거창지역의 과실은 $50.3 \%$ 수준 으로 낮은 과피장해 발생률을 보여 '홍로' 사과의 과피장해 발생을 억제하기 위해서는 저장온도를 $0^{\circ} \mathrm{C}$ 보다 $4^{\circ} \mathrm{C}$ 로 설정 하는 것이 바람직하다고 판단되었다. 이는 '콕스오렌지피 핀', ‘크립스핑크', ‘엠파이어', ‘허니크리스프' 등과 같은 저장온도에 민감한 사과 품종의 경우 저장온도를 높여주었 을 때 저장장해가 억제되었다 $(10,11,13,15)$ 는 결과와도 일 치하였다.

과피의 음각장해증상에서 병원균을 분리한 결과 4 종의 곰팡이가 분리되었으며(Fig. 5), 이들 각각의 곰팡이로부터 total genomic DNA를 추출하여 ITS영역을 증폭 후 분석하 였다. 획득한 염기서열은 미국 국립생물공학정보센터 (NCBI)에서 BLAST 방법을 통해 상동성 분석을 한 결과 획득된 염기서열은 각각 Penicillium sp.(MH865544), Alternaria sp.(MG827168), Phoma sp.(KR708991), Botryosphaeria dothidea(MG595271)와 99-100\%의 높은 상 동성을 나타내었으며, 배양학적 특성과 균학적 특징 역시 분석결과와 동일한 결과를 나타내어 분리된 4종의 곰팡이 는 각각 Penicillium sp., Alternaria sp., Phoma sp., 및 B. dothidea로 확인되었다. 하지만 과피에서 관찰된 음각증상 과 위의 병원균들이 직·간접적으로 영향을 미쳤는지에 대 해서는 추가적인 연구가 필요할 것으로 판단되었다.

\section{상관관계 분석}

저장온도에 따라 두 지역 '홍로' 사과의 과실품질과 과피 저장장해에 상이한 상관관계를 보이고 있다(Fig. 6). $4^{\circ} \mathrm{C}$ 저장 처리시 재배지역과 무관하게 왁스 발생정도와 내생에 틸렌 발생량은 $0^{\circ} \mathrm{C}$ 저장처리구와 비교하여 높은 정의 상관 관계를 보였으며, 특히 거창지역에서 더 높은 정의 상관관
계 $(\mathrm{r}=0.553)$ 를 보였다. 이는 에틸렌의 증가가 가역적으로 왁스의 발생을 촉진시킨다(22)는 연구결과와 동일한 결과 를 보였다. 과피 저장장해 역시 $4^{\circ} \mathrm{C}$ 에 저장한 과실이 $0^{\circ} \mathrm{C}$ 에 저장한 과실과 비교하여 낮은 상관관계를 보이며 특히, 거 창지역의 $4^{\circ} \mathrm{C}$ 에 저장한 과실에서 과피 저장장해와 내생에 틸렌 발생량 간에 음의 상관관계(r=-0.723)를 보여 온도로 인하여 에틸렌 발생량이 증가하더라도 과피장해는 오히려 감소하는 결과를 보였다. 이는 저온저장시 온도를 $0^{\circ} \mathrm{C}$ 에서 $3^{\circ} \mathrm{C}$ 로 높였을 때 저장장해의 발생이 감소하였다는 보고와 동일한 연구결과를 보였다(17).

이상의 결과를 종합해 보면, '홍로' 사과를 $4^{\circ} \mathrm{C}$ 에 저장하 였을 때 내생에틸렌 발생량과 왁스발생정도는 $0^{\circ} \mathrm{C}$ 저장과 비교하여 다소 증가하였지만, 과실품질 특성 기준인 경도, 산 함량, 가용성 고형물 함량은 차이가 없었다. 특히, 최근 다발생하고 있는 음각형태의 과피 저장장해의 경우 $4^{\circ} \mathrm{C}$ 에 저장하였을 때 $0^{\circ} \mathrm{C}$ 저장과 비교하여 장해발생률이 15.6$50.3 \%$ 수준으로 감소하는 결과를 보였다. 그리고 이러한 과피 음각증상에서 4 종의 병원균이 동정되어 어떠한 연관 성이 있는지에 대한 추가적인 검토가 필요하다고 사료된 다. 따라서 '홍로' 사과를 수확후 저장시 과실품질의 변화 없이 과피의 음각장해의 발생 피해를 줄이기 위해서는 그동 안 관행적으로 저장하는 온도인 $0^{\circ} \mathrm{C}$ 보다는 $4^{\circ} \mathrm{C}$ 에 저장하는 것이 효과적인 저장방법이라고 판단되었다.

\section{요 약}

본 연구는 온도를 달리한 저온저장 처리가 ‘홍로' 사과의 저장중 과실 품질과 과피 저장장해 발생에 미치는 영향을 구명하고자 실시하였다. '홍로' 과실은 경상북도 문경과 경상남도 거창지역에서 각각 수확하였으며, $0^{\circ} \mathrm{C}$ 와 $4^{\circ} \mathrm{C}$ 저장 조건에서 각각 4 개월간 저장하며 과피장해 및 과실특성을 조사하였다. 저장기간동안 ‘홍로' 사과의 품질변화를 보면 경도와 산 함량은 저장기간이 길어질수록 다소 감소하였으 나 저장온도에 따른 차이는 없었다. 가용성 고형물 함량은 저장기간 동안 처리간 차이가 없었다. 반면 내생에틸렌 발 생량은 두 지역 모두 $4^{\circ} \mathrm{C}$ 저장처리구에서 $0^{\circ} \mathrm{C}$ 저장처리구 보다 그 발생량이 증가하였고, 과피의 왁스 발생정도 역시 두 지역 모두 $4^{\circ} \mathrm{C}$ 저장처리구에서 그 발생정도가 증가되었 다. 그리고 과피 저장장해는 저장 4 개월 후 $4{ }^{\circ} \mathrm{C}$ 저장처리구 가 $1.3-4.7 \%$ 로, $0^{\circ} \mathrm{C}$ 저장처리구 8.1-9.4\%와 비교하여 낮은 장해발생률을 보였다. 장해증상 부분에서 병원균을 분리한 결과 푸른곰팡이병, 점무늬낙엽병, 점무늬병, 겹무늬썩음 병 등 4종이 동정되었다. 따라서, '홍로' 사과의 과피 저장장 해 발생을 억제하기 위하여 과실을 $0^{\circ} \mathrm{C}$ 에서 저장하는 것보 다 $4^{\circ} \mathrm{C}$ 에서 저장하는 것이 효과적이라고 판단된다. 


\section{감사의 글}

본 연구는 2017년 농촌진흥청(과제번호: PJ01245502) 연 구비지원에 의해 이루어진 것임.

\section{References}

1. Han SG, Yun TM (2004) Effects od crop load on leaf water relations, growth and fruit quality of 'Hongro' apple trees. Korean J Hortic Sci Technol, 22, 37-37

2. Mir NA, Curell E, Khan N, Whitaker M, Beaudry RM (2001) Harvest maturity, storage temperature, and 1-MCP application frequency alter firmness retention and chlorophyll fluorescence of 'Redchief Delicious' apples. J Am Soc Hortic Sci, 126, 618-624

3. Lim BS, Yun SK, Nam EY, Chun JP, Cho MA, Chung DS (2013) Effects of storage temperature and 1-MCP treatment on postharvest quality in plumcot hybrid $\mathrm{cv}$. Harmony. Korean J Hortic Sci Technol, 31, 203-210

4. Yoo J, Kang BK, Lee J, Kim DH, Lee DH, Jung HY, Choi DG, Choung MG, Choi IM, Kang IK (2015) Effect of preharvest and postharvest 1-methylcyclopropene (1-MCP) treatments on fruit quality attributes in cold-stored 'Fuji' apples. Korean J Hortic Sci Technol, 33, 542-549

5. Jung SK, Watkins CB (2011) Involvement of ethylene in browning development of controlled atmosphere-stored 'Empire' apple fruit. Postharvest Biol Technol, 59, 219-226

6. Lee J, Cheng L, Rudell DR, Watkins CB (2012) Antioxidant metabolism of 1-methylcyclopropene (1-MCP) treated 'Empire' apples during controlled atmosphere storage. Postharvest Biol Technol, 65, 79-91

7. Chu CL (1999) Effects of storage temperature, storage atmosphere, and growing region on internal browning disorder of 'McIntosh' apples. HortTechnology, 9, 75-78

8. DeEll JR, Prange RK (1998) Disorders in 'Cortland' apple fruit are induced by storage at $0^{\circ} \mathrm{C}$ in controlled atmosphere. HortScience, 33, 121-122

9. Watkins CB, Liu FW (2010) Temperature and carbon dioxide interactions on quality of controlled atmospherestored 'Empire' apples. HortScience, 45, 1708-1712

10. Johnson DS (2010) Investigating the cause of diffuse browning disorder in CA-stored Cox's Orange Pippin apples. Acta Hortic, 857, 205-212
11. James H, Jobling J, Tanner D (2008) Investigating structural and physiological differences between radial and diffuse types of flesh browning in Cripps Pink apples. Acta Hortic, 768, 77-84

12. Burmeister DM, Dilley DR (1995) A 'scald-like' controlled atmosphere storage disorder of Empire apples-a chilling injury induced by $\mathrm{CO}_{2}$. Postharvest Biol Technol, 6, 1-7

13. Jung SK, James H, Lee J, Nock JF, Watkins CB (2010) Effects of ethylene inhibition on development of flesh browning in apple fruit. Acta Hortic, 877, 549-554

14. Kweon HJ, Kang IK, Kim MJ, Lee J, Moon YS, Choi C, Choi DG, Watkins CB (2013) Fruit maturity, controlled atmosphere delays and storage temperature affect fruit quality and incidence of storage disorders of 'Fuji' apples. Sci Hortic, 157, 60-64

15. Moran RE, DeEll JR, Murr DP (2010) Effects of preconditioning and fruit maturity on the occurrence of soft scald and soggy breakdown in 'Honeycrisp' apples. HortScience, 45, 1719-1722

16. Tong CBS, Bedford DS, Luby JJ, Propsom FM, Beaudry RM, Mattheis JP, Watkins CB, Weis SA (2003) Location and temperature effects on soft scald in 'Honeycrisp' apples. HortScience, 38, 1153-1155

17. Watkins CB, Nock JF, Weis SA, Jayanty S, Beaudry RM (2004) Storage temperature, diphenylamine, and pre-storage delay effects on soft scald, soggy breakdown and bitter pit of 'Honeycrisp' apples. Postharvest Biol Technol, 32, 213-221

18. Smock RM, Neubert AM (1950) Economic crops: apples and apple products, vol 2. Interscience, New York, NY, USA, p 486

19. Snowdon AL (1990) A color atlas of post-harvest diseases and disorders of fruits and vegetables, vol 1. CRC Press, Boca Raton, FL, USA, p 213

20. Dadzie B, Banks N, Hewett E, Cleland D (1995) Reduced greasiness of 'Granny smith' apples washed in tween 20 solution. N Z J Crop Hortic Sci, 23, 219-222

21. Hardenburg RE, Watada AE, Wang CY (1986) The commercial storage of fruits, vegetables, and florist and nursery storks. USDA, Agric handbook No 66, Washington DC, USA, p 130

22. Lim BS, Park YM, Hwang YS, Do GR, Kim KH (2009) Influence of ethylene and 1-methylcyclopropene treatment on the storage quality of 'Hongro' apples. Korean J Hortic Sci, 27, 607-611 